\title{
Gastrointestinal Complications
}

\author{
Grzegorz W. Basak
}

\subsection{Introduction}

The gastrointestinal (GI) tract is one of the systems most commonly affected by transplant complications. It is due to the high vulnerability of the gut mucosa composed of dividing cells, which are susceptible to chemotherapy-induced damage, rich vasculature, constant contact with intestinal microflora, and high content of immune-competent cells. Therefore, when evaluating symptoms from the GI system, various possible causes must be taken into account, especially drug toxicity, infections, and graft-versus-host disease. In this chapter selected GI complications most frequent after HSCT will be presented. The GI aGVHD was already discussed in Chaps. 43 and 44 and infectious causes in Chaps. 38 and 39.

\subsection{Nausea/Vomiting}

\subsubsection{Definitions}

Nausea: a disorder characterized by a queasy sensation and/or the urge to vomit.
Vomiting: a disorder characterized by the reflexive act of ejecting the contents of the stomach through the mouth.

\subsubsection{Types}

Acute onset: within $24 \mathrm{~h}$ of chemotherapy administration (peak at 4-6 h) lasting for 24-48 h.

Delayed onset: occurs more than $24 \mathrm{~h}$ after chemotherapy (peak at 2-3 days) lasting for prolonged period of time.

\subsubsection{Pathophysiology}

1. Direct activation of the vomiting center in the brain stem by chemotherapy, which triggers target organs in GI tract.

2. Damage to the GI mucosa, causing vagal stimulation and neurotransmitter (serotonin, neurokinin-1, dopamine) release causing reflexive stimulation of the vomiting center.

3. Radiotherapy-induced neurotransmitter release stimulating vomiting center concomitant with brain edema.

G. W. Basak ( $\square)$

Department of Hematology, Oncology and Internal

Medicine, Independent Public Central Clinical

Hospital, Medical University of Warsaw,

Warsaw, Poland

e-mail: grzegorz.basak@wum.edu.pl 


\subsubsection{Causes}

Induced directly by conditioning chemoradiotherapy TBI, TLI, cranio-spinal irradiation

Chemotherapy drugs (NCCN 2017):

- High emetic risk (frequency $>90 \%$ ):

$\mathrm{CY}>1500 \mathrm{mg} / \mathrm{m}^{2}, \mathrm{BCNU}>250 \mathrm{mg} / \mathrm{m}^{2}$

- Moderate emetic risk (frequency 30-90\%): bendamustine, BU, BCNU $\leq 250 \mathrm{mg} / \mathrm{m}^{2}$, $\mathrm{CY} \leq 1500 \mathrm{mg} / \mathrm{m}^{2}, \mathrm{MEL}$

- Minimal to low emetic risk (frequency < 30\%): VP, TT, FLU, MTX $\leq 50 \mathrm{mg} / \mathrm{m}^{2}$

Drugs: opioids, CNI, nystatin, AmB, voriconazole, itraconazole, TMP-SMX, MMF

GVHD

Hepatic disease: GVHD, VOD, viral hepatitis Infection: CMV, HSV, VZV, fungal, bacterial, norovirus, rotavirus, parasites

Adrenal insufficiency

Pancreatitis

\subsubsection{Diagnosis}

Based on symptoms.

\subsubsection{Grading (CTCAE v4.0 [NCl 2009])}

\begin{tabular}{|c|c|}
\hline \multicolumn{2}{|l|}{ Nausea } \\
\hline Grade 1 & $\begin{array}{l}\text { Loss of appetite without alteration of eating } \\
\text { habits }\end{array}$ \\
\hline Grade 2 & $\begin{array}{l}\text { Oral intake decreased without significant } \\
\text { weight loss, dehydration, or malnutrition }\end{array}$ \\
\hline Grade 3 & $\begin{array}{l}\text { Inadequate oral caloric or fluid intake, tube } \\
\text { feeding, TPN, or hospitalization indicated }\end{array}$ \\
\hline \multicolumn{2}{|l|}{ Vomiting } \\
\hline Grade 1 & $1-2$ episodes (separated by $5 \mathrm{~min}$ ) in $24 \mathrm{hs}$ \\
\hline Grade 2 & $3-5$ episodes (separated by $5 \mathrm{~min}$ ) in $24 \mathrm{~h}$ \\
\hline Grade 3 & $\begin{array}{l}\geq 6 \text { episodes (separated by } 5 \mathrm{~min} \text { ) in } 24 \mathrm{~h} \text {, } \\
\text { tube feeding, TPN, or hospitalization } \\
\text { indicated }\end{array}$ \\
\hline Grade 4 & $\begin{array}{l}\text { Life-threatening consequences, urgent } \\
\text { intervention indicated }\end{array}$ \\
\hline
\end{tabular}

\subsubsection{Treatment}

Prevention of nausea/vomiting is the mainstay of clinical management since treatment frequently proves ineffective. Delayed nausea should be treated with scheduled antiemetics for 2-4 days after completion of chemotherapy.

\subsubsection{Prophylaxis}

Choice of drugs depends on the use of drug with highest emetogenic potential (NCCN 2017):

\begin{tabular}{|c|c|}
\hline $\begin{array}{l}\text { High emetic } \\
\text { risk }\end{array}$ & $\begin{array}{l}\text { Serotonin ( } 5 \text {-HT3 antagonist) (patients } \\
\text { should be monitored for QT corrected } \\
\text { prolongation) } \\
\text { - Short-acting: ondansetron } 3 \times 8 \mathrm{mg} \text { IV } \\
\text { on days of chemo }+24-48 \mathrm{~h} \text {, } \\
\text { granisetron, dolasetron } \\
\text { - Long-acting: palonosetron } 0.25 \mathrm{mg} \mathrm{IV} \text {, } \\
\text { may be repeated every } 3 \text { days } \\
\text { Plus } \\
\text { Neurokinin-1 receptor antagonists, e.g., } \\
\text { aprepitant } \\
\text { Plus/minus } \\
\text { Dexamethasone } 2-10 \text { mg IV (as } \\
\text { required for a short duration) }\end{array}$ \\
\hline $\begin{array}{l}\text { Moderate } \\
\text { emetic risk }\end{array}$ & $\begin{array}{l}\text { Serotonin (5-HT3) antagonists (as } \\
\text { above) } \\
\text { Plus/minus } \\
\text { Dexamethasone } 2-10 \mathrm{mg} \mathrm{IV}\end{array}$ \\
\hline $\begin{array}{l}\text { Low emetic } \\
\text { risk }\end{array}$ & $\begin{array}{l}\text { Serotonin (5-HT3) antagonists (short } \\
\text { acting, as above) } \\
\text { Metoclopramide } \\
\text { Prochlorperazine }\end{array}$ \\
\hline TBI & $\begin{array}{l}\text { Serotonin (5-HT3) antagonists (short- or } \\
\text { long-acting, as above) } \\
\text { Dexamethasone ( } 4 \mathrm{mg} / \mathrm{d} \text { or } 4 \mathrm{mg} \text { bid) }\end{array}$ \\
\hline
\end{tabular}

\subsubsection{Other Nausea/Vomiting}

$\begin{array}{ll}\begin{array}{l}\text { Breakthrough } \\ \text { treatment }\end{array} & \begin{array}{l}\text { Addition of a different class } \\ \text { anti-emetic drug } \\ \text { Prochlorperazine (10 mg IV q6h) } \\ \text { Haloperidol (1-2 mg q4h) } \\ \text { Metoclopramide }(0.5-2 \mathrm{mg} / \mathrm{kg} \mathrm{IV} \\ \text { q6h) } \\ \text { Olanzapine } \\ \text { Scopolamine transdermal patch } \\ \text { Corticosteroids }\end{array} \\ \begin{array}{l}\text { Lorazepam } \\ \text { Anticipatory }\end{array} & \begin{array}{l}\text { Prevention of nausea/vomiting by } \\ \text { efficient prophylaxis at every } \\ \text { treatment } \\ \text { Strong smell avoidance }\end{array} \\ & \begin{array}{l}\text { Behavioral therapy } \\ \text { Lorazepam, alprazolam }\end{array}\end{array}$




\subsection{Diarrhea}

\subsubsection{Definitions}

A disorder characterized by frequent and watery bowel movements.

\subsubsection{Physiopathogeny}

Depending on the cause.

\subsubsection{Causes}

The diarrhea in preengraftment period is most frequently caused by toxicity of conditioning. In post transplant period, aGVHD must be taken into consideration. The risk of infectious causes persists for the whole time with bacterial causes predominating relatively earlier than viral infections.

\section{Chemotherapy and radiation therapy-related toxicity Acute GVHD \\ Intestinal infections: \\ - Clostridium difficile \\ - Viral (CMV, VZV, rotavirus, norovirus, astrovirus, adenovirus) \\ - Parasitic (giardia, strongyloides, cryptosporidium) \\ - Fungal (candida) \\ Medications (antibiotics, mycophenolate mofetil, oral nutritional supplements) \\ Transplant-associated microangiopathy \\ Other: pancreatitis/pancreatic insufficiency, lactose intolerance/disaccharidase deficiency, malabsorption, inflammatory bowel disease, liver and gallbladder disease}

\subsubsection{Diagnosis}

The standard workup for diarrhea after HSCT includes stool cultures, tests for Clostridium difficile toxin A and B, Clostridium antigen, stool and/or blood tests for viruses, and, when negative, endoscopy with biopsy for aGVHD and CMV. However, when these tests are proven negative, a broad area of causes must be considered (Robak et al. 2017).
Stool examination and microbiological workup

- $C$. difficile toxin, antigen, culture

- Parasites (giardia, strongyloides, cryptosporidium)

- Viruses (CMV, VZV, rotavirus, norovirus, astrovirus, adenovirus)

- Fungi (culture)

Sigmoidoscopy/colonoscopy \pm gastroscopy

- Histopathology for GVHD, cryptosporidium, and CMV

- Viral, parasitic/bacterial cultures

Biochemistry (triglycerides, amylase, lipase), GVHD biomarkers (calprotectin, REG3- $\alpha$ ) (RodriguezOtero et al. 2012; Ferrara et al. 2011)

Ultrasound, CT (in GVHD distal ileum or proximal colon most likely involved)

Capsule endoscopy

\subsubsection{Grading}

When the diagnosis of gut aGVHD is established or suspected, aGVHD grading should be used as described in Chap. 43. Otherwise, (CTCAE v4.0) grading should be used (NCI 2009).

Grade 1 Increase of $<4$ stools per day over baseline; mild increase in ostomy output compared to baseline

Grade 2 Increase of 4-6 stools per day over baseline; moderate increase in ostomy output compared to baseline

Grade 3 Increase of $\geq 7$ stools per day over baseline; incontinence; hospitalization indicated; severe increase in ostomy output compared to baseline; limiting self- care activities of daily living

Grade 4 Life-threatening consequences; urgent intervention indicated

\subsubsection{Treatment}

Targeted, according to the known or suspected cause, consider overlap with another pathology (e.g., aGVHD with gut $\mathrm{CMV}$ infection)

Ancillary: modification of diet

- Lactose- or gluten-free

- Restricted diet (low roughage, low residue, low or no lactose)

- Temporarily nothing per os and TPN Avoid fluid loss and dyselectrolytemia Monitor and replace protein losses (albumin, gamma globulin)

Loperamide 2-4 mg p.o. every $6 \mathrm{~h}$ if associated with toxicity of conditioning or GVHD

Octreotide 


\subsection{Esophagitis/Gastritis}

\subsubsection{Definitions/Symptoms}

Heartburn and/or epigastric pain observed most frequently during conditioning and period of mucositis.

\subsubsection{Causes}

Mucositis, medications, altered gastric $\mathrm{pH}$, peptic ulcer disease, and fungal esophagitis.

\subsubsection{Diagnosis}

Based on clinical symptoms \pm endoscopy.

\subsubsection{Treatment}

Depending on the cause, elevation of the head of bed, and consideration of proton pump inhibitors and other symptomatic treatments (e.g., alginate, antacid, and topical local anesthetics, such as oxetacaine for mucositis). May require systemic analgesia if patient unable to swallow.

\subsection{Gl Bleeding}

\subsubsection{Definitions/Symptoms}

May appear as melena, hematemesis or bloody stool, or emergence of normocytic anemia.

\subsubsection{Causes}

Thrombocytopenia, esophageal trauma, esophagitis, colitis, anal fissures or varices, viral infections, GVHD, and plasma coagulation impairment.

\subsubsection{Diagnosis}

Esophagogastroduodenoscopy, colonoscopy, and angioCT.
50.5.4 Treatment

Treatment of underlying disorder

Symptomatic

- Platelet transfusion to $>50 \times 10^{9} / \mathrm{L}$

- RBC transfusion

- Fresh frozen plasma, fibrinogen concentrates, vitamin K supplementation

- Octreotide

- Endoscopic cauterization or embolization

When massive blood loss

- Desmopressin

- Tranexamic acid

- Recombinant factor VII

\subsection{Typhlitis}

\subsubsection{Definitions/Symptoms}

Necrosis of usually large intestinal wall associated with chemotherapy toxicity and bacterial overgrowth.

Occurs within 30 days after HSCT, patients usually complain of pain in right lower abdominal quadrant, often with associated fever.

Additionally, nausea, emesis, increased abdominal wall tension, and watery bloody diarrhea may occur (Robak et al. 2017).

\subsubsection{Causes}

Toxicity/infection.

\subsubsection{Diagnosis}

Clinical and abdominal ultrasound or CT: bowel wall thickening usually limited to single region, e.g., ileocecal or ascending colon; may be associated with perforaton and air within intestinal wall.

\subsubsection{Treatment}

Antibiotics and bowel rest. Avoid surgical intervention. 


\subsection{Pancreatic Disease}

\subsubsection{Definitions/Symptoms}

Pancreatic insufficiency and atrophy or acute pancreatitis.

\subsubsection{Causes}

Medications (prednisone, tacrolimus), stones, and pancreatic GVHD.

\subsubsection{Diagnosis}

Insufficiency and atrophy: low serum trypsinogen, high fecal elastase-1, and possible atrophy in imaging. Acute pancreatitis: elevated lipase and amylase, elevated fecal fat, and edema in ultrasound/CT.

\subsubsection{Treatment}

When insufficiency: enzyme replacement.

\subsection{Chronic Esophageal GVHD}

\subsubsection{Definitions/Symptoms}

Dysphagia to solid food, chest discomfort, and aspiration (Jagasia et al. 2015; Robak et al. 2017)

\subsubsection{Diagnosis}

Barium meal: mid/upper esophageal strictures, webs, rings, bullae, and desquamation. Endoscopy: as above, erythematous, friable sloughed mucosa.

\subsubsection{Treatment}

When severe and chronic, need serial dilations and enteral tube placement or esophagectomy.

\section{Key Points}

The workup and management of GI complications after HCT follow general medical approach; however the most frequent scenarios remain characteristic for this patient population. The most common causes include toxicity of drugs, especially those used for conditioning, infection, and/ or graft-versus-host disease:

- Nausea/vomiting or diarrhea occurring before engraftment is most likely caused by toxicity of conditioning, while after engraftment, GVHD needs to be considered, especially in allo-HSCT setting.

- For the whole post transplant period, infectious causes should also be considered with bacterial or fungal causes predominating in the neutropenic period and viral reactivations/infections in the later phases.

- Importantly, inflammation caused by infection may become a trigger to GVHD, while GVHD is frequently followed by infection; therefore, overlapping scenarios always need to be taken into account.

- GI GVHD is frequently a diagnosis of exclusion (especially in patients with other overlapping causes which may impact on laboratory investigations). However, it should always be considered when symptoms persist despite extensive workup and/or directed treatment.

\section{References}

Common Terminology Criteria for Adverse Events (CTCAE). Version 4.0. Published: May 28, 2009 (v4.03: June 14, 2010) U.S. Department of Health and Human Services, National Institutes of Health, National Cancer Institute. https://www.eortc. be/services/doc/ctc/CTCAE_4.03_2010-06-14_ QuickReference_5x7.pdf

Ferrara JL, Harris AC, Greenson JK, et al. Regenerating islet-derived 3-alpha is a biomarker of gastrointestinal graft-versus-host disease. Blood. 2011;118:6702-8. 
Jagasia MH, Greinix HT, Arora M, et al. National Institutes of Health Consensus Development Project on Criteria for Clinical Trials in Chronic Graft-versusHost Disease: I. The 2014 Diagnosis and Staging Working Group report. Biol Blood Marrow Transplant. 2015;21:389-401.

NCCN Clinical Practice Guidelines in Oncology (NCCN Guidelines). Antiemesis. Version 2.2017. March 28, 2017. https://www.nccn.org/professionals/physician_ gls/pdf/antiemesis.pdf
Robak K, Zambonelli J, Bilinski J, Basak GW. Diarrhea after allogeneic stem cell transplantation: beyond graft-versus-host disease. Eur J Gastroenterol Hepatol. 2017;29:495-502.

Rodriguez-Otero P, Porcher R, Peffault de Latour R, et al. Fecal calprotectin and alpha-1 antitrypsin predict severity and response to corticosteroids in gastrointestinal graft-versus-host disease. Blood. 2012;119:5909-17.

Open Access This chapter is licensed under the terms of the Creative Commons Attribution 4.0 International License (http://creativecommons.org/licenses/by/4.0/), which permits use, sharing, adaptation, distribution and reproduction in any medium or format, as long as you give appropriate credit to the original author(s) and the source, provide a link to the Creative Commons license and indicate if changes were made.

The images or other third party material in this chapter are included in the chapter's Creative Commons license, unless indicated otherwise in a credit line to the material. If material is not included in the chapter's Creative Commons license and your intended use is not permitted by statutory regulation or exceeds the permitted use, you will need to obtain permission directly from the copyright holder. 